УДК 633.34:631.526.32:631.67

DOI https://doi.org/10.32848/agrar.innov.2021.5.7

\title{
ВОДОСПОЖИВАННЯ РОСЛИН СОЇ ЗАЛЕЖНО ВІД СОРТУ, СИСТЕМИ ЗАХИСТУ
}

\author{
ЗАЄЦь С.О. - кандидат сільськогосподарських наук \\ https://orcid.org/0000-0001-7853-7922 \\ Інститут зрошуваного землеробства Національної академії аграрних наук України \\ РудІк О.Л. - кандидат сільськогосподарських наук \\ https://orcid.org/0000-0003-1384-5523 \\ Інститут зрошуваного землеробства Національної академії аграрних наук України \\ ЮзюК С.М. - кандидат сільськогосподарських наук \\ https://orcid.org/0000-0001-8761-642X \\ Інститут зрошуваного землеробства Національної академії аграрних наук України \\ HETIC I.T. - доктор сільськогосподарських наук \\ https://orcid.org/0000-0002-7075-2107 \\ ФУНдИРАТ К.С. - кандидат сільськогосподарських наук \\ https://orcid.org/0000-0001-8343-2535 \\ Інститут зрошуваного землеробства Національної академії аграрних наук України
}

Постановка проблеми. Соя як високорентабельна культура, що має великий і стабільний попит на внутрішньому і світовому ринках, займає значні площі посіву на зрошуваних землях Півдня України. За оцінками економістів, вона є однією з найбільш прибуткових польових культур, а рентабельність ії̈ вирощування за зрошення, незважаючи на високі меліоративні витрати, у середньому становить 50-90\%, зростаючи до $110-115 \%$ за врожайності 4,0 т/га [1-5].

Однак високопродуктивні посіви сої надзвичайно вразливі до шкідників та хвороб, а затрати на систему захисту становлять значну частку виробничих витрат. Сучасні системи захисту рослин побудовані переважно на застосуванні хімічних препаратів, без яких у сучасних умовах практично неможливе економічно прибуткове виробництво. Проте низка негативних явищ, які виникають у разі масового використання хімічних препаратів, таких як резистентність у популяціях шкідливих організмів, знищення корисної біоти, пестицидне забруднення ценозу, загальний негативний вплив на середовище існування людини, зумовлює актуальність розроблення альтернативних заходів боротьби, де надзвичайно перспективним напрямом $€$ біологізація інтенсивного виробництва. Збереження попередніх темпів хімізації стає технологічно небезпечним, оскільки виникнення стійких форм шкідливих організмів випереджає створення нових препаратів.

В Інституті зрошуваного землеробства на протязі останнього десятиліття створено низку сортів сої, що виділяються підвищеною продуктивністю, за рахунок упровадження яких можна значно збільшити виробництво зерна сої в Україні.

Ïх успішне впровадження потребує розроблення сучасних систем хімічного та біологічного захисту рослин від хвороб і шкідників на зрошуваних землях Півдня України відповідно до сортових особливостей їх росту і розвитку.

Саме ураження шкідниками та хворобами не дає можливості повною мірою реалізувати потенціал таких поширених сортів, як Даная, Діоната і Святогор, що робить цю проблему досить актуальною.

Аналіз останніх досліджень і публікацій. Збільшення світового виробництва продуктів харчу- вання на $70 \%$ для забезпечення продовольчої безпеки зростаючого населення до 2020 р. може бути досягнуто виключно за рахунок зростання продуктивності, що потребує обґрунтованого забезпечення посівів вологою та ефективної системи захисту сільськогосподарських культур (Mutei (2011), Câmara \& Heiffing (2000)).

Соя дуже чутлива до умов навколишнього середовища, а основними кліматичними чинниками, що впливають на врожайність, $€$ світловий, водний та тепловий режими (Mundstock \& Thomas, 2005). В умовах арідного клімату нестача води $€$ основним обмежуючим чинником, який визначає величину врожаю сої (Casagrande et al, 2001), впливаючи на використання інших ресурсів навколишнього середовища. Наявність водного стресу може знизити врожайність на 50\% незалежно від кліматичних умов (Lisar et al. (2012)). За таких обставин рослини зазнають низки незворотних змін у своїй морфології, фрізіології і біохімії, що негативно впливає на їх ріст і продуктивність (Gerten \& Rost (2010)). Зважаючи, що дві третини світового виробництва продуктів харчування вирощується в умовах нестачі води, у контексті глобальних змін клімату більшість сільськогосподарських культур зазнаватиме негативних впливів, викликаних посухою.

Ефективність використання ресурсів та рівень продуктивності посівів сої суттєво залежить від здоров'я рослин, тривалості активної роботи листового апарату та зменшення витрат пластичних речовин на протидію негативному впливу шкідливих організмів. У такому розрізі система захисту, підтримуючи адекватний розвиток рослин протягом усього їх життєвого циклу, є ефективним комплексним заходом впливу на продукційний процес [6-9].

Мета. Метою досліджень $є$ вивчення впливу систем хімічного та біологічного захисту рослин і водоспоживання сучасних сортів сої під час вирощування в умовах зрошення.

Матеріали та методика досліджень. Дослідження проводили в Інституті зрошуваного землеробства НААН на масиві Інгулецької зрошуваної системи з використанням сортів сої Даная, Діона і Святогор. Система захисту рослин від шкідників та хвороб передбачала три фони: контроль - без застосування фунгіцидів та інсектицидів 
(фон: протруювання насіння Максим XL 035 FS (1.0 л/т), інокуляція препаратом Оптімайз в.р. (2,8 л/т) і застосування ґрунтового гербіциду Фронтьєр Оптіма к.е. $(1.4 \mathrm{л} /$ га)); хімічний - фон + Абакус $(1,5$ л/га) $(\mathrm{BBCH}$ 50) та фрунгіцид Ретенго (0,5 л/га) з інсектицидом Белт (0,1 л/га) (ВВСН 69); біологічний - фон + біофунгіцид Псевдобактерін 2 (2,0 л/га) (ВВСH 50) та біофунгі- цид Бактофріт (2,5 л/га) і біоінсектицид Лепідоцид-БТУ (10,0 л/га) (ВВСН 69). Інокуляцію посівного матеріалу проводили препаратом Оптімайз у день сівби з витратами препарату 2,8 л/т.

Двофакторний дослід був закладений методом розщеплених ділянок у чотириразовій повторності, загальна площа ділянки становила 25,0 м², облікової -

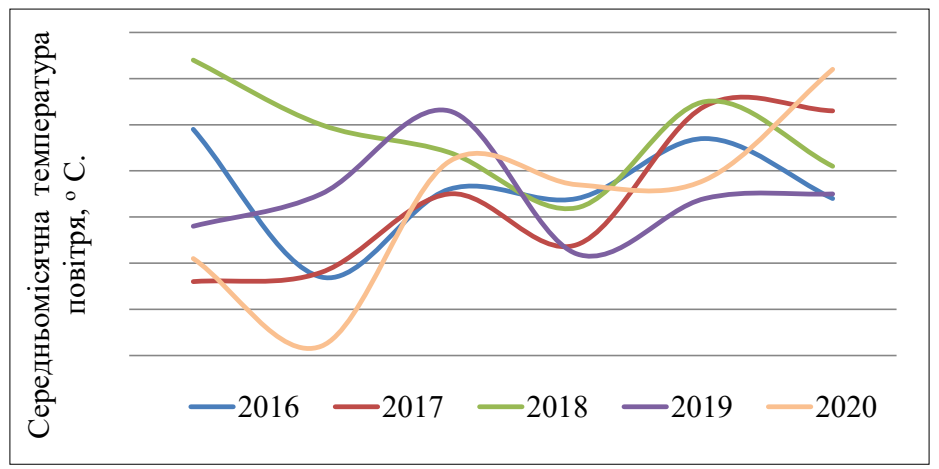

Рис. 1. Відхилення середньомісячних температур повітря від норми впродовж періоду вегетації сої Примітка: середні значення за 1983-2010 рр.

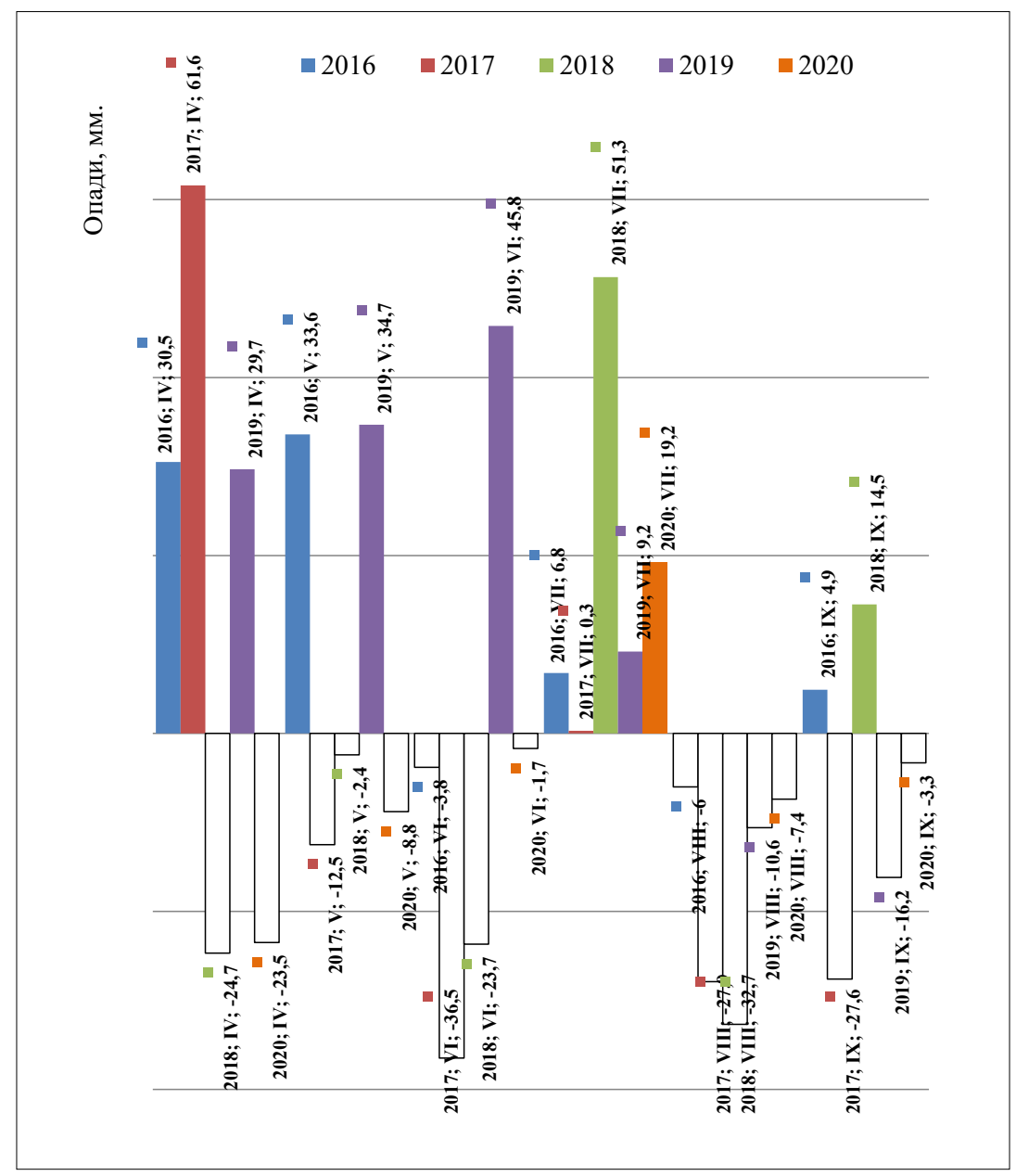

Рис. 2. Відхилення від норми суми опадів впродовж періоду вегетації сої Примітка: середні значення за 1983-2010 рр. 


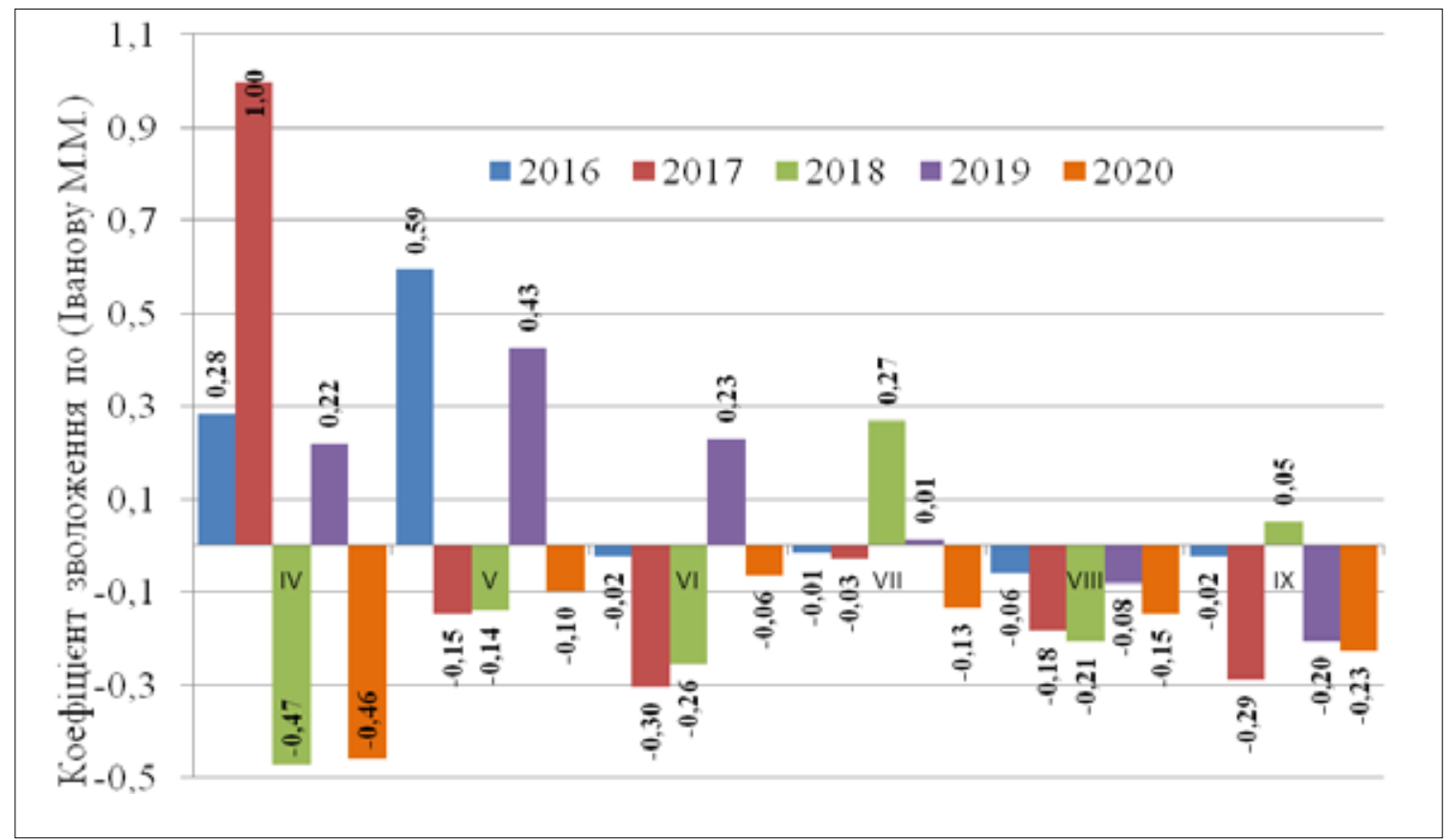

Рис. 3. Відхилення від норми коефіцієнту зволоження впродовж періоду вегетації сої

Примітка: середні значення за 1983-2010 рр.

20,0 м². У досліді застосовували зональну рекомендовану технологію вирощування культури за зрошення.

Вегетаційні поливи проводили за допомогою дощувального агрегату ДДА-100МА.

Збирання й облік урожаю здійснювали прямим комбайнуванням облікової ділянки з використанням комбайну Sampo-130.

Результати досліджень. Вирощування сої у роки досліджень відбувалося переважно за підвищеного температурного режиму та нестабільного рівня надходження опадів.

Підвищений температурний режим весняного періоду 2016, 2018 та 2019 рр. дав змогу раніше середніх термінів розпочати сівбу культури. У 2017 та 2020 рр. через низькі температури посів проводився пізніше середніх багаторічних термінів. Проте подальший розвиток рослин упродовж усіх років досліджень проходив за підвищеного температурного режиму. Особливо значним було перевищення норми температур упродовж серпня, коли у рослин сої завершувалося цвітіння та тривало формування бобів (рис. 1).

На початку вегетації найбільш сприятливими щодо вологозабезпечення були 2016, 2017 та 2019 рр. Проте генеративний період росту та розвитку сої в усі роки досліджень був переважно несприятливим щодо надходження опадів.

Винятком було лише значне перевищення опадів у червні 2019 р. та липні 2018 та 2020 рр. (рис. 2).

Упродовж усіх років період наливу бобів та дозрівання проходив за жарких і посушливих умов, що вимагало інтенсивного зрошення. У цілому за період вегетації культури надійшло від 81 мм опадів у 2017 р. до 248 мм у 2019 р. За таких умов для підтримання рекомендованого режиму зрошення було проведено від шести до восьми поливів, а зрошувальна норма коливалася від 2300 м³/га у 2019 р. до 2900 м³/га y 2018 p.

Зважаючи на значне перевищення температурного режиму та нерівномірне надходження опадів, умови в період вирощування сої можна охарактеризувати як надзвичайно посушливі. Коефіцієнт зволоження за М.М. Івановим за середніх значень 0,3 коливався від 0,11 та 0,17 у 2017 та 2020 рр., що характерно для зони напівпустель, до 0,38 та 0,4 у 2019 та 2016 рр.

Коефіцієнт зволоження у період вегетації сої за роки досліджень знаходився в межах 0,11-0,37, що вказує на посушливість клімату, і такі показники притаманні природній зоні напівпустелі.

За вологозабезпеченням найбільш сприятливими був 2019 р., коли впродовж квітня-червня спостерігалися значно вологіші умови завдяки надходженню опадів, навіть на тлі перевищення температурного режиму.

Такі особливості гідротермічних умов зумовлювали великі потреби в зрошенні та провокували появу численних популяцій шкідників сої, особливо павутинного кліща, що зумовлювало необхідність проведення заходів захисту (рис. 3).

Соя належить до культур, що потребують інтенсивного зрошення. У середньому за період досліджень вирощування сої потребувало 4913-5428 м³/га вологи. Використання сортів, різних за тривалістю вегетаційного періоду, впливає на величину сумарного водоспоживання. У середньому за період досліджень сумарне водоспоживання середньостиглих сортів сої Святогор і Даная було більшим на 491 і 448 м³/га порівняно з ранньостиглим сортом Діона (табл. 1). Запровадження біологічної та хімічної системи захисту проявляло незначний вплив на загальну кількість спожитої вологи (0,9-4,4\%), а відхилення від контролю було зумовлене виключно використанням запасів ґрунтової вологи та коливалося в межах від 5 до 22 м³/га. 
Таблиця 1 - Водоспоживання сортів сої залежно від різних систем захисту рослин (середнє за 2016-2020 рр.)

\begin{tabular}{|c|c|c|c|c|c|c|c|c|c|}
\hline \multirow{3}{*}{ Сорт (A) } & \multirow{3}{*}{$\begin{array}{c}\text { Система } \\
\text { захисту } \\
\text { рослин } \\
\text { (В) }\end{array}$} & \multicolumn{6}{|c|}{ Складники водоспоживання } & \multirow{3}{*}{$\begin{array}{c}\text { Сумарне } \\
\text { водоспо- } \\
\text { живання, } \\
\text { м³/га }\end{array}$} & \multirow{3}{*}{$\begin{array}{c}\text { Коефріцієнт } \\
\text { водоспо- } \\
\text { живання, } \\
\text { м3/т }\end{array}$} \\
\hline & & \multicolumn{2}{|c|}{$\begin{array}{c}\text { ґрунтова } \\
\text { волога }\end{array}$} & \multicolumn{2}{|c|}{ опади } & \multicolumn{2}{|c|}{ поливи } & & \\
\hline & & $\mathbf{M}^{3} / \mathbf{r a}$ & $\%$ & $\mathrm{M}^{3} / \mathrm{ra}$ & $\%$ & $\mathrm{M}^{3} / \mathbf{r a}$ & $\%$ & & \\
\hline \multirow{3}{*}{ Діона } & контроль & 736 & 14,7 & 1535 & 31,5 & 2430 & 49,6 & 4913 & 1890 \\
\hline & біозахист & 745 & 14,9 & 1535 & 31,5 & 2430 & 49,5 & 4922 & 1789 \\
\hline & хімзахист & 758 & 15,1 & 1535 & 31,4 & 2430 & 49,4 & 4935 & 1732 \\
\hline \multirow{3}{*}{ Даная } & контроль & 875 & 16,2 & 1626 & 30,2 & 2810 & 52,7 & 5362 & 1672 \\
\hline & біозахист & 881 & 16,3 & 1626 & 30,1 & 2810 & 52,7 & 5369 & 1590 \\
\hline & хімзахист & 895 & 16,5 & 1626 & 30,0 & 2810 & 52,6 & 5382 & 1546 \\
\hline \multirow{3}{*}{ Святогор } & контроль & 928 & 16,9 & 1626 & 29,8 & 2810 & 52,3 & 5416 & 1908 \\
\hline & біозахист & 934 & 17,0 & 1626 & 29,8 & 2810 & 52,2 & 5421 & 1777 \\
\hline & хімзахист & 940 & 17,1 & 1626 & 29,7 & 2810 & 52,2 & 5428 & 1748 \\
\hline & & & & & & \multicolumn{2}{|c|}{$\bar{X} \pm S_{\bar{x}}$} & $5239 \pm 183$ & $1739 \pm 94$ \\
\hline & & & & & & \multicolumn{2}{|c|}{$V, \%$} & 4,54 & 7,02 \\
\hline
\end{tabular}

Сорт Діона раніше за інші сорти дозрівав, а тому потребував меншої кількості поливів. У середньому за період спостережень зрошувана норма для цього сорту становила 2430 м³/га та була на 380 м³/га меншою, ніж у середньостиглих сортів Даная та Святогор. Менше сорт Діона споживав і ґрунтової вологи - 736-758 м³/га порівняно із сортом Даная (875-895 м³/га) та сортом Святогор (928-940 м³/га). Більш короткий період вегетації сорту сої Діона призвів до надходження меншої кількості опадів, що в середньому за період спостережень становило $91 \mathrm{~m}^{3} /$ га.

Ефективність використання вологи визначається одночасно сумарним вологоспоживанням та врожайністю культури. Більш економно споживали вологу рослини сорту Даная, коефіцієнт водоспоживання якого залежно від системи захисту становив 1546-1672 м³/т. Сорти Діона і Святогор потребували для формування 1 т зерна відповідно 1748-1908 та 1732-1890 м³ води.

Здійснюючи незначний вплив на величину сумарного водоспоживання, система захисту рослин завдяки підвищенню врожайності культури позитивно впливає на ефективність використання вологи.

Запровадження системи хімічного захисту зумовлювало зменшення коефіцієнту волоспоживання на 126-160 м³/т, а біологічного залежно від сорту на $82-131 \mathrm{~m}^{3} / \mathrm{T}$. Зазначена ефрективність у досліджуваних системах захисту рослин була зумовлена більшою врожайністю усіх сортів сої на тлі застосування хімічних препаратів. У розрізі сортового складу найбільш виразною була реакція на запровадження систем захисту у сорту сої Святогор, На тлі біологічного захисту зменшення сумарного водоспоживання становило $131 \mathrm{~m}^{3} / \mathrm{T}$, а хімічного - $160 \mathrm{~m}^{3} / \mathrm{T}$.

У середньому за роками досліджень було встановлено, що найвищу частку у сумарному водоспоживанні сої становить зрошувана норма 49,4-52,7\%, а другорядну - опади (29,7-31,5\%), тоді як частка ґрунтової вологи становила $14,7-17,1 \%$.

У середньому за фрактором В (захист) основна частка в балансі сумарного водоспоживання належала вегетаційним поливам і становила на сорті Святогор - 52,2\%, на сорті Даная - 52,7\% і сорті Діона - 49,5\% (рис. 4).

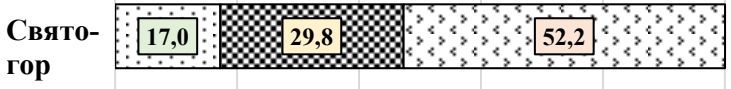

Даная

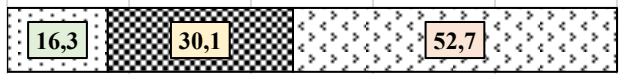

Діона

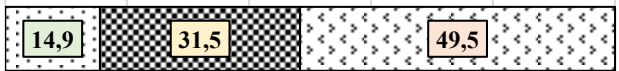

$\mathbf{0} \%$

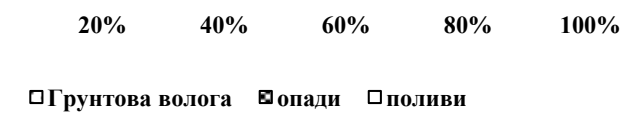

Рис. 4. Дольова участь ґрунтової вологи, опадів

і поливів у балансі сумарного водоспоживання сортів сої, 2016-2020 pp.

Результати економічного аналізу свідчать, що сорти, строки сівби та застосування систем захисту рослин суттєво впливають на показники економічної ефективності вирощування сої. Вартість валової продукції з 1 га на системах захисту рослин була більшою на 9-10\% за застосування біологічних препаратів та на 3-18\% - за застосування хімічних, аніж на ділянках контролю (без захисту) залежності від сорту, що пов'язано з вищою врожайністю.

Запровадження системи захисту рослин зумовлює істотне збільшення виробничих витрат, унаслідок чого на контролі без захисту рослин виробничі витрати становили 19168-23800 грн/га, тоді як за застосування біологічного і хімічного захисту - відповідно 19858-24628 і 20340-25206 грн/га. Однак при цьому прибуток зростав від 9242 тис грн на контролі до 11056 тис грн за застосування в системі захисту біологічних препаратів та до 10864 тис грн за використання пестицидів у середньому по фактору.

За результатами розрахунків найнижчою була собівартість зерна сорту Даная як за біологічної, так 
і за хімічної систем захисту та становила відповідно 7395,68 і 7243,10 грн/т.

Висновки. Вирощування сої в зрошуваних умовах Півдня України потребує проведення 6-7 поливів зрошуваною нормою 2100-2700 м³/га. Найбільшу частку сумарного водоспоживання культури становить зрошувана норма 49,4-52,7\%, опади - 29,7-31,5\%.

Запровадження системи хімічного та біологічного захисту посівів сої зумовлює незначне зростання водоспоживання культури, проте підвищує ефективність використання води. Найвищу окупність вологи забезпечує використання сорту сої Даная - $1590 \mathrm{~m}^{3} / \mathrm{T}$ за системи біологічного та $1546 \mathrm{~m}^{3} / \mathrm{T}$ за системи хімічного захисту посівів.

Найвищий прибуток забезпечує використання сорту сої Даная за системи біологічного захисту, при цьому собівартість зерна $€$ найменшою і становить 6675,15 грн/т, собівартість зерна, отримана на сорті Святогор, за хімічної системи захисту рослин 6911,52 грн/т, на сорті Діона за хімічної - 7324,50 грн/т. На цих варіантах отримано і найбільший умовно чистий прибуток і рівень рентабельності - 13280 і 11520 грн/га та $60 \%$ і $55 \%$ відповідно.

\section{СПИСОК ВИКОРИСТАНОЇ ЛІТЕРАТУРИ:}

1. Білоусов О.М. Організаційно-економічний механізм розвитку діяльності підприємств з виробництва та переробки сої: теорія, методологія, практика : автореф. дис. ... док. екон. наук : 08.00.04 «Економіка та управління держпідприємствами». Херсон, 2011. 37 с.

2. Грановська Л.М., Клубук В.В. Ефективність вирощування сої сортів селекції Інституту зрошуваного землеробства НААН. Посібник українського хлібороба. 2014. T. 3. C. $36-37$

3. Маслак О. Соєві жнива 2015. Агробізнес сьогодні. 2015. № 20(315). C. 15-20.

4. Genetic diversity and population structure of vegetable soybean (Glycine max (L.) Merr.) in China as revealed by SSR markers Genet / Dong D. et al. Resour. Crop Evol., 61 2014. P. 173-183.

5. Physiological status of'king'squab pigeon (Columba Livia gm. Cv.€'king') in biogeochemical conditions of low iodine, selenium and cobalt levels in the environment. / V.I. Vorobyev et al. Asia Life Sci., 28 (1) (2019). P. 99-110.

6. Gustavo M. Souza, Tiago A. Catuchi, Suzana C. Bertolli and Rogerio P. Soratto. Soybean Under Water Deficit: Physiological and Yield Responses, A Comprehensive Survey of International Soybean Research - Genetics, Physiology, Agronomy and Nitrogen Relationships, James E. Board, IntechOpen (January 2nd 2013). DOI: 10.5772/54269. URL: https://www.intechopen. com/books/a-comprehensive-survey-of-internationalsoybean-research-genetics-physiology-agronomy-andnitrogen-relationships/soybean-under-water-deficitphysiological-and-yield-responses.

7. Information on soybean irrigation is provided by Douglas J. Jardine, Professor Emeritus, Kansas State University. 7/2020 URL: https://soybeanresearchinfo.com/ agronomics/soybean-irrigation/.

8. Soybean irrigation and water use. University of Missouri Extension, 2017. URL: http://crops.missouri.edu/ irrigation/.
9. Kranz W.L., Specht J.E. 2012. Irrigating soybean. NebGuide G1367. University of Nebraska-Lincoln Extension. Irrigating soybeans. Publication G4420. University of Missouri Extension.

\section{REFERENCES:}

1. Bilousov, O.M. (2011). Orhanizatsiino-ekonomichnyi mekhanizm rozvytku diialnosti pidpryiemstv $z$ vyrobnytstva ta pererobky soi: teoriia, metodolohiia, praktyka [Organizational and economic mechanism for the development of the activities of enterprises for the production and processing of soybeans: theory, methodology, practice]. Extended abstract of Doctor's thesis. Kherson [in Ukrainian].

2. Hranovska, L.M. \& Klubuk, V.V. (2014). Efektyvnist vyroshchuvannia soi sortiv selektsii Instytutu zroshuvanoho zemlerobstva NAANU [Efficiency of growing soybean varieties of the Institute of Irrigated Agriculture UAAS]. Posibnyk Ukrayins'koho khliboroba -Handbook of Ukrainian farmers, 3, 36-37 [in Ukrainian].

3. Maslak, O. (2015) Soievi zhnyva [Soybean harvest]. Zhurnal Ahrobiznes sohodni - Agribusiness magazine today, 20(315), 15-20 [in Ukrainian].

4. Dong, D. et al. (2018). Genetic diversity and population structure of vegetable soybean (Glycine max (L.) Merr.) in China as revealed by SSR markers Genet. Resour. Crop Evol, 61, 173-183.

5. Vorobyev, V.I. et al. (2019). Physiological status of'king'squab pigeon (Columba Livia gm. Cv.€'king') in biogeochemical conditions of low iodine, selenium and cobalt levels in the environment. Asia Life Sci, 28(1), 99-110

6. Gustavo, M. Souza, Tiago, A. Catuchi, Suzana, C Bertolli \& Rogerio, P. Soratto. (2013). Soybean Under Water Deficit: Physiological and Yield Responses, A Comprehensive Survey of International Soybean Research - Genetics, Physiology, Agronomy and Nitrogen Relationships, IntechOpen, DOI: 10.5772/ 54269. Available from: https://www.intechopen.com/ books/a-comprehensive-survey-of-internationalsoybean-research-genetics-physiology-agronomy-andnitrogen-relationships/soybean-under-water-deficitphysiological-and-yield-responses

7. Information on soybean irrigation is provided by Douglas J. Jardine, Professor Emeritus. (2020) Kansas State University, 7. URL: https://soybeanresearchinfo.com/ agronomics/soybean-irrigation/

8. Soybean irrigation and water use. University of Missouri Extension. (2017) URL: http://crops.missouri.edu/ irrigation/

9. Kranz, W.L. \& Specht, J.E. (2012). Irrigating soybean (NebGuide G1367). University of Nebraska-Lincoln Extension. URL: https://www.dekalbasgrowdeltapine.com/ en-us/agronomy/soybean-water-use-and-irrigationtiming.html

Заєць С.О., Рудік О.Л., Юзюк С.М., Нетіс І.Т.,

Фундират К.С. Водоспоживання рослин сої залежно від сорту, систем захисту

Мета. Вивчення впливу систем хімічного та біоло-гічного захисту рослин та водоспоживання сучасних сортів сої під час вирощування в умовах зрошення. Методи. Дослідження проводили в Інституті зрошу-ваного землеробства НАAН на масиві Інгулецької 
зрошуваної системи з використанням сортів сої Даная, Діона і Святогор. Система захисту рослин від шкідників та хвороб передбачала три фони: контроль - без застосування фунгіцидів та інсектицидів; хімічний - фон; біологічний - фон. Інокуляцію посівного матеріалу проводили препаратом Оптімайз у день сівби з витратами препарату 2,8 л/т. Збирання й облік урожаю здійснювали прямим комбайнуванням облікової ділянки із використанням комбайну Sampo 130. Результати. Коефіцієнт зволоження у період вегетації сої за роки досліджень знаходився в межах 0,11-0,37, що вказує на посушливість клімату, такі показники притаманні природній зоні напівпустелі. Більш економно споживали вологу рослини сорту Даная, коефіцієнт водоспоживання якого залежно від системи захисту становив 1546-1672 м³/т. Сорти Діона і Святогор потребували для формування 1 т зерна відповідно 1748-1908 та 1732-1890 м³ води. Система захисту рослин підвищує врожайність культури, позитивно впливає на ефективність використання вологи. Виходячи 3 розрахунків, найнижчою була собівартість зерна сорту Даная як за біологічної, так і за хімічної систем захисту та становила відповідно, 7395,68 і 7243,10 грн/т. Висновки. Найвищий прибуток забезпечує використання сорту сої Даная за системи біологічного захисту, при цьому собівартість зерна $€$ найменшою і становить 6675,15 грн/т, собівартість зерна, отримана на сорті Святогор, за хімічної системи захисту рослин - 6911,52 грн/т та на сорті Діона за хімічної - 7324,50 грн/т. На цих варіантах отримано і найбільший умовно чистий прибуток і рівень рентабельності 13280 і 11520 грн/га та 60\% і 55\% відповідно.

Ключові слова: зрошення, сорти, фон захисту, інокуляція, урожайність, рентабельність.

Zaets S.O., Rudik O.L., Netis I.T., Yuzyuk S.N., Fundirat K.S. Water consumption of soybean plants depending on the variety, protection system

Purpose. study of the effect of chemical and biological plant protection systems and water consumption of modern soybean varieties when grown under irrigation conditions. Methods. The research was carried out at the Institute of Irrigated Agriculture of the NAAS on the Ingulets irrigated system using the soybean varieties Danae, Diona and Svyatogor. The system of plant protection against pests and diseases provided for three backgrounds: control - without the use of fungicides and insecticides; chemical - background; biological - background. The inoculation of the seed material was carried out with the Optimize preparation on the day of sowing with a consumption of $2.8 \mathrm{l} / \mathrm{t}$. The harvesting and accounting of the crop was carried out by direct combining of the registration area using a Sampo 130 combine. Results. The moisture coefficient during the growing season of soybeans for the years of research was in the range of $0.11-0.37$, which indicates the aridity of the climate, such indicators are typical for the natural semi-desert zone. Plants of the Danae variety consumed water more economically, the coefficient of water consumption, which, depending on the protection system, was 1546$1672 \mathrm{~m}^{3} / \mathrm{t}$. The varieties Diona and Svyatogor required 1748-1908 and 1732-1890 $\mathrm{m}^{3}$ of water for the formation of 1 ton of grain, respectively. Plant protection system, increases crop yields, positively affects the efficiency of water use. Based on the calculations, the lowest cost of grain of the Danae variety was when using a biological and chemical protection system, and amounted, respectively, to 7395.68 and $7243.10 \mathrm{UAH} /$ t. Findings. A high income is ensured by the use of the Danae soybean variety in the biological protection system, while the cost of grain is the lowest and amounts to $6,675.15 \mathrm{UAH} / \mathrm{t}$, the cost of grain was obtained on the Svyatogor variety in the chemical plant protection system - 6911.52 UAH/t and on the Diona variety in chemical $-7324.50 \mathrm{UAH} / \mathrm{t}$. On these options, the highest conditionally net profit and the level of profitability were obtained - 13280 and $11520 \mathrm{UAH} / \mathrm{ha}, 60$ and $55 \%$, respectively.

Key words: Irrigation, varieties, background of protection, inoculation, productivity, profitability. 